\title{
Managing factoring in banking groups
}

ARTICLE in SSRN ELECTRONIC JOURNAL · JANUARY 2006

DOI: $10.2139 /$ ssrn. 1004060 - Source: RePEc

READS

24

2 AUTHORS:

Paola Schwizer

Università degli studi di Parma

29 PUBLICATIONS 34 CITATIONS

SEE PROFILE
Gianluca Mattarocci

University of Rome Tor Vergata

69 PUBLICATIONS 21 CITATIONS

SEE PROFILE 


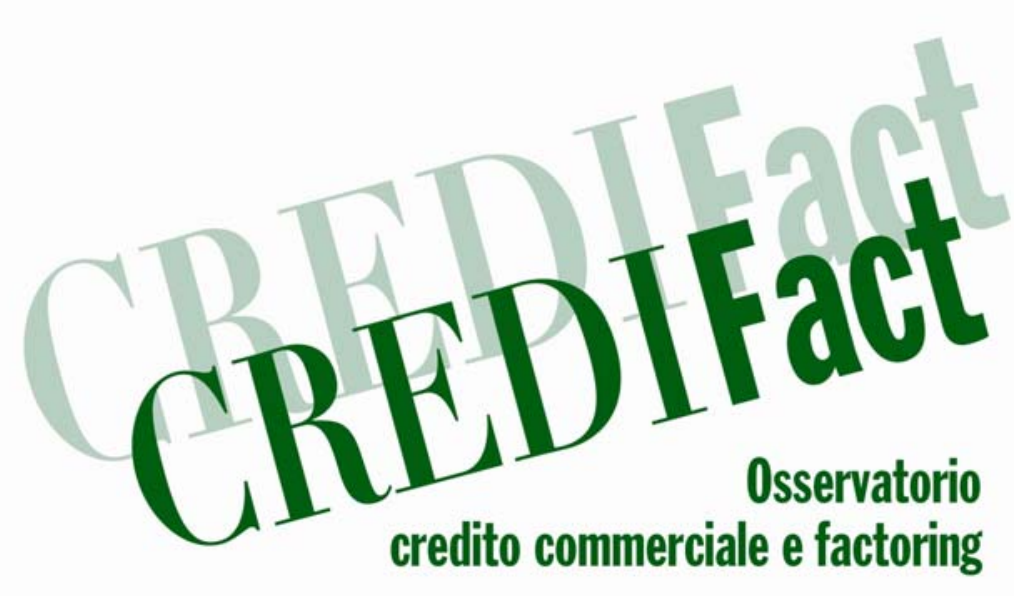

\title{
Managing factoring in banking groups
}

\author{
by \\ Paola Schwizer \\ University of Parma \\ and \\ Gianluca Mattarocci \\ University of Rome "Tor Vergata"
}

\section{Discussion Paper Series}

n. $1 / 2006$

April 2006

JEL classification: G21, L22, L89

Keywords: factoring, group organizations, institutional models

Supplement to Fact\&News n.2- 2006

Credifact è promosso da

Assifact - Associazione Italiana per il Factoring

Via Cerva, 9 - 20122 Milano

Telefono: 00390276020127 - Telefax:00 390276020159

credifact@assifact.it-www.assifact.it 


\section{Abstract}

The market for factoring services is characterized by the coexistence of independent companies and companies belonging to banking groups. While group intermediaries may be steered in their decisionmaking processes by the policies of their parent company, they are likely to benefit from synergies, if any, with the other financial intermediaries they are connected with.

The main advantages stem from the opportunity to streamline costs, to make the most of the experience gained by the individual members of the group, and to have access to greater financial resources. Whenever such areas of interdependence are singled out and turned to account, the group factors may succeed in attaining a competitive advantage over independent intermediaries.

On the other hand, in evaluating the impact that joining a banking group may have, one needs to consider the level of interchangeability among the various services that may be rendered by the latter, the inter-relations that may emerge in the various phases of the productive process, and the organizational problems that may affect the banking group.

This analysis highlights the complementariness of the factoring service with respect to other financial products, evaluates the likely presence of significant synergies in a few stages of the productive process and singles out a methodology to assess the level of cohesion of the group and the type of control wielded by the parent company.

\section{CREDIFact}




\section{Introduction ${ }^{1}$}

In recent years, the market for financial services witnessed a growth in the level of concentration in supply that set a limit to the number of independent intermediaries working in the individual countries. ${ }^{2}$ The most widespread solution to increase market share has been the creation of a financial group with a holding bank that coordinates the other intermediaries and directs their supply-oriented policies in order to make the most of the overall result. ${ }^{3}$

The Italian factoring market is characterized by the coexistence of independent factoring companies and companies controlled by banking groups. While the latter may be steered in their decision-making by group policies, they benefit from synergies with the other financial intermediaries they are connected with. ${ }^{4}$ The factors belonging to a group may be subjected to varying levels of influence by the parent company but, whatever the case may be, the study of their behavior points to significant differences with respect to the behavior of independent intermediaries. ${ }^{5}$

Statistics of the Bank of Italy on the supply of factoring services highlight a decrease in the number of companies controlled by banking groups in consequence of bank concentration processes; in any event, such a decrease is sided by an increase in the market share of these intermediaries (Graph 1).

\footnotetext{
${ }^{1}$ This report is the outcome of the cooperative effort of the two authors. The individual parts may be attributed as follows: the introduction and paragraph 3.2 have been worked out by Paola Schwizer, while paragraphs 2, 3.1, 3.3, 3.4 and the conclusions have been drafted by Gianluca Mattarocci.

Paola Schwizer is full professor of Banking at the University of Parma.

Gianluca Mattarocci is a Ph.D. in "Banking and Finance" at the University of Rome "Tor Vergata".

${ }^{2}$ Lown C.S. et al. (2000), "The changing landscape of the financial service industry: what lies ahead", Federal Reserve Bank of New York Policy Review, vol. 6, pp. 39-55

${ }^{3}$ Carretta A. (1986), "Le banche e la gestione delle attività non bancarie: alcuni profili organizzativi", Banca, Impresa e Società, vol. 1, pp. 81-95.

${ }^{4}$ Carretta A. (1991), "Analisi del modello istituzionale del gruppo plurifunzionale: condizioni di dimensione per il funzionamento", in Vanciago G. (1991) Manuale per il 1993 e oltre - scelte strategiche e organizzative, Edibank, Milano.

5 Carretta A. (1998), "Effetti della formazione di aggregati bancari sul comportamento e sulle performance delle istituzioni finanziarie", in Aidea (1998), Proceedings of the meeting on "Corporate strategies and policies", CLUEB, Bologna
} 


\section{Graph 1}

Relevance of banking groups in the factoring market

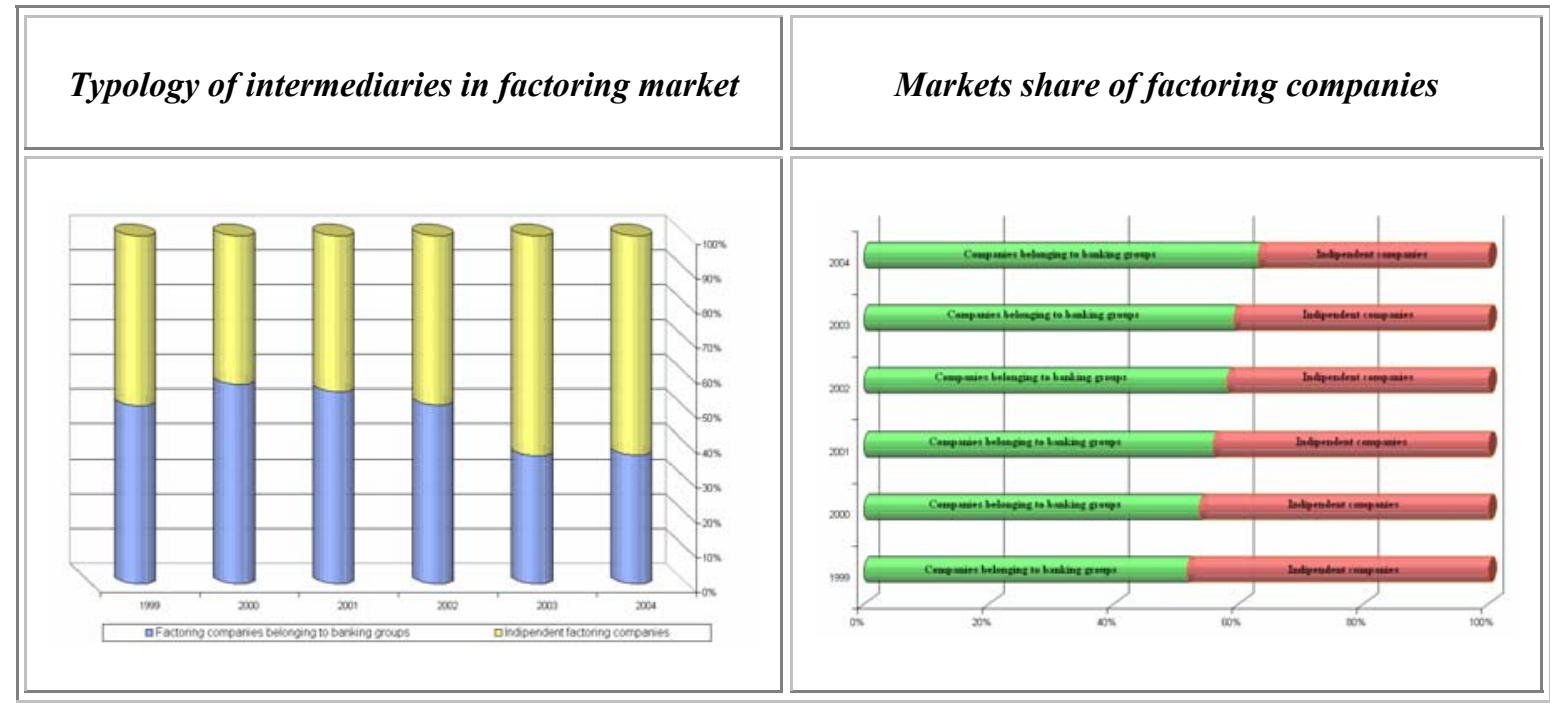

Source: Authors' processing of Bank of Italy data

The leading actors in the Italian market are often required to interact with holding banks and other entities belonging to a group and the prevalence of such an organizational solution in medium-large companies would seem to highlight the existence of considerable group synergies. The main advantages stem from the opportunity to streamline costs and to make the most of the experience gained by the individual members of the group, as well as from the possibility to have access to greater financial resources. ${ }^{6}$

The purpose of this paper is to analyze the potential synergies between factoring companies and other financial intermediaries set up within a group, and to assess the advantage of the recourse to the banking group formula for carrying out factoring activities. After a review of the theories proposed by the literature to warrant the adoption of the group structure, and the main merits and defects of such an organizational model (paragraph 2), the papers reviews the advantages and limits of being a part of a group for a factoring company (paragraphs 3.1 and 3.2). Finally, it proposes an analysis of the group effectiveness based on a measurement of the influence wielded by the parent company and the level of cohesion among members (paragraph $3.3)$.

${ }^{6}$ Soufani K. (2002), "The decision to finance account receivables: the factoring option", Managerial and Decision Economics, vol. 23, pp. 21-32. 


\section{Strengths and weaknesses of conglomerates}

From an organizational point of view, the conglomerate is a solution that succeeds in matching diversification and flexibility, since it allows working in different sectors and making the most of the potential synergies among members without giving rise to an excessively rigid corporate structure. ${ }^{7}$ A number of economic objectives are associated with the group setup, such as:

$>$ search for benefits resulting from the attainment of vertical ${ }^{8}$ and/or horizontal ${ }^{9}$ integrations;

$>$ pursuit of economies of scale and/or scope; ${ }^{10}$

$>$ recourse to economies of specialization ${ }^{11}$ and/or experience; ${ }^{12}$

$>$ reduction of corporate governance costs. ${ }^{13}$

In fact, the setting up of a group may be an effective solution to minimize the overall corporate risk through an integration with distributors or suppliers (vertical integrations $)^{14}$ or an increase in the market share in consequence of more stable relations with potential competitors (horizontal integrations). ${ }^{15}$ Such an organizational solution permits to attain the objective of expanding the scope of corporate operations and reducing the volatility of the resulting profits without calling for the creation of an excessively rigid corporate organization. ${ }^{16}$

A conglomerate may use the available resources to minimize costs and maximize results through its dimensional growth and productive diversification. In fact, the decision to growth inside the industry (economies of scale) ${ }^{17}$ and/or to diversify in correlated industries (economies of scope) ${ }^{18}$ allows an allocation of fixed costs on a greater number of products and services and, being conditions equal, an increase in the profit margin on individual operations.

The intermediaries' experience, their knowledge of the business and expertise represent distinctive factors that may determine the success of an enterprise. The creation of a

\footnotetext{
${ }^{7}$ Vander Vennet R. (2002), "Cost and profit efficiency of financial conglomerates and universal banks in Europe", Journal of Money, Credit and Banking, vol. 34, pp. 254-282.

${ }^{8}$ Coase R.H. (1937), “The nature of the firm", Economica, vol. 4, pp. 386-405.

${ }^{9}$ Richardson G.B. (1972), “The organization of industry", Economic Journal, vol. 82, pp. 883-896.

${ }^{10}$ Teece D.J. (1980), "Economies of scope and the scope of enterprise", Journal of Economic Behavior and organization, vol. 1, pp. 223-247.

${ }^{11}$ Eccles R.J. (1981), "The quasi firm in the construction industry", Journal of Economic Behavior and Organization, vol. 2, pp. 335-357.

${ }^{12}$ Turati C. (1990), Economia ed organizzazione delle joint ventures, EGEA, Milano.

${ }^{13}$ Williamson O.E. (1985), The economic institutions of capitalism, Free Press, Oxford.

${ }^{14}$ Blois K.J. (1972), "Vertical quasi integration”, Journal of Industrial Economics, vol. 20, pp. 253-272.

${ }^{15}$ Walter I. (1999), Financial services strategies in the Euro zone, Stern Working paper, New York.

${ }^{16}$ Galaskiewicz J. (1985), "Interorganizational relations”, Annual Review of Sociology, vol. 11, pp. 281304.

${ }^{17}$ Berger A.N. and Hannan T.H. (1998), "The efficiency cost of market power in the banking industry: a test of the 'quiet life' and related hypotheses", Review of Economics and Statistics, vol. 80, pp. 454-465.

${ }^{18[}$ Amel D et al. (2002), Consolidation and efficiency in the financial sector: a review of the international evidence, Temi di discussione Banca d'Italia, no.464.
} 
group allows the specialization of the resources belonging to individual divisions in the provision of a few services, with a potential maximization of the benefits linked to the exploitation of the so-called "experience curves". ${ }^{19}$ Furthermore, the presence within a group of entities characterized by heterogeneous training curricula and expertise creates the conditions for the inner development of product and/or process innovations that allow making the most of the synergies among group members. ${ }^{20}$

Finally, the group structure allows a reduction in the costs linked to governance problems that may affect enterprises working in a number of industries. ${ }^{21}$ In fact, this solution permits to avoid the centralization of all the decision-making processes and to grant autonomy to group members, providing merely for inner and outer control mechanisms that are likely to safeguard the interest of all the stakeholders in the individual enterprises. ${ }^{22}$

The effectiveness of group organization depends on the ability to limit the risk of an uncoordinated behavior of group members and, therefore, the risk that the resulting flexible structure might prove inefficient being unable to make the most of the potential benefits. On the other hand, the extent of the resulting benefits depends on:

$>$ the level of heterogeneity of the entities involved in terms of objectives being pursued, which may result in a lower capability to coordinate the activity of the persons belonging to the group, ${ }^{23}$

$>$ the ability to create value through the best possible utilization of the complementary competences present within the group; ${ }^{24}$

$>$ the presence of pre-existing relations among the enterprises giving rise to the group that, therefore, may be handled under more advantageous inner conditions once the new organizational model is adopted; ${ }^{25}$

$>$ the complexity of the individual operations, which may call for a higher or lower level of autonomy of the enterprises belonging to the group that work in a few specific industries; ${ }^{26}$

$>$ the number of entities involved that, should it be too high, may give rise to coordination problems. ${ }^{27}$

${ }^{19}$ Grandori A. and Soda G. (1995), "Inter-firm networks: antecedents, mechanisms and forms", Organization Studies, vol. 16, pp.183-214.

${ }^{20}$ Van Lelyveld I. and Schilder A. (2003), Risk in financial conglomerates: management and supervision, Brooking and Warthon papers on Financial Services, London.

${ }^{21}$ Gradori A. (1997), "Governance structure, coordination mechanism and cognitive models", Journal of Management and Governance, vol. 1, pp. 29-47.

${ }^{22}$ Bethel J.E. and Porter Liebeskind J. (1998), "Diversification and the legal organization of the firm", Organization Science, vol. 9, pp. 49-67.

${ }^{23}$ Porter M. (1981), "The contributions of industrial organization to strategic management", Academy of Management Review, vol. 6, pp. 609-620.

${ }^{24}$ Teece J. (1989), "Inter-organizational requirements of the innovation process", Managerial and Decision Economics, vol. 10, pp. 35-42.

${ }^{25}$ Van de Ven A.H. (1976), "A framework for organizational assessment", Academy of Management Review, vol. 1, pp. 64-78.

${ }^{26}$ Osborn R. (1950), "The relative efficiency of large, medium-sized and small business", Accounting Review, vol. 25, pp. 262-273.

${ }^{27}$ Phillips A. (1960), "A theory of interfirm organization", Quarterly Journal of Economics, vol.74, 
The joint analysis of these aspects permits to single out, in the individual cases, the entities to be included within the group, to evaluate the benefits resulting from the adoption of this organizational structure, and to determine the hierarchy of relations to be established in the new corporate architecture.

\section{Advantages and limits of belonging to a banking group for factoring companies}

Heterogeneous financial services may be offered having recourse to a variety of organizational forms and the actual choice among the various opportunities at hand depends on the characteristics of both the services provided and the intermediaries involved. A different pay-off between coordination costs and benefits resulting from the flexibility and the considerable ability to interact with other businesses of the sector may be highlighted based on the peculiar characteristics of the company taken into consideration. $^{28}$

The advantages/limits linked to a group solution may be probed into by considering the level of diversification of the group's product portfolio, the possibility of maximizing the result and/or minimizing the costs linked to a few phases of the productive process and the coordination problems, if any, within the banking group. The three profiles of analysis being proposed are reviewed in the paragraphs below with reference to the factoring activity. More specifically, the factoring services and the inner processes of a factor are reviewed with a view to defining a model allowing the evaluation of the expediency of the banking group model in rendering such a service.

\subsection{A comparison between factoring service and other financial instruments}

The factor operates by buying from the selling company their invoiced credits. These are purchased, usually without recourse, by the factor who then will be responsible for all credit control, collection and sales accounting work. ${ }^{29}$

Factoring is a form of asset-based lending that combines:

- receivables financing; ${ }^{30}$

- an insurance service, present in non-recourse assignments, that - in the event of the insolvency of the assigned debtor - rules out the factor's right to have recourse against the client; ${ }^{31}$

\footnotetext{
pp. 602-613.

${ }^{28}$ Carretta A. (1995), Il factoring, Ricerche Newfin-Università Commerciale Bocconi, Milano, pp. 43-49.

${ }^{29}$ Monferrà S. (2003), "Il factoring: servizi di gestione, assicurazione e finanziamento", in Fabrizi P.L. et al. (edited by), Strumenti e servizi finanziari, Egea, Milano.

${ }^{30}$ Benvenuti M. and Gallo M. (2004), Perché le imprese ricorrono al factoring? Il caso dell'Italia, Temi di discussione Banca d'Italia no. 518.

${ }^{31}$ Bakker M.R. et al. (2004), Financing small and medium-size enterprise with factoring: global growth
} 
- a managerial component represented by a series of support services that the factor may render to clients with a view to improving ${ }^{32}$ and/or facilitating the management of the customer/debtor portfolio. ${ }^{33}$

A factoring agreement may attach more or less relevance to the services outlined above and, depending on the actual service offered to clients, a factoring agreement may be broken down into three macro-categories: recourse factoring (pro solvendo), nonrecourse factoring (pro soluto), and maturity factoring.

Recourse assignments require the factoring company to evaluate the risk of assigned debtors and guarantors, if any, and the likely presence - merely as a risk-lessening factor - of an assignor in respect of which the company has the right of recourse in the case of insolvency of the assigned debtor. In the analysis of the exposures, the type of relationship established with debtors needs to be taken into account. The notnotification factoring agreements do not require that the debtor be informed about the transfer of accounts payable to a factor and, as a rule, payment is regularly made to the assigner who undertakes to transfer the subsequently collected funds to the factor. On the other hand, the notification factoring agreements give rise to a more direct relationship between the factor and the assigned debtor. ${ }^{34}$

The maturity factoring agreement entails no financial support since factor does not pay in advance respect to the natural due date of assigned credits. Under this type of agreement, the factor supplies merely ancillary services, and there is no financial risk associated with this type of relationships. ${ }^{35}$

In non-recourse factoring assignments, the factor takes on the guarantee of the solvency of the debtors, but the contractual practice may provide for mitigating clauses that lay down the persistence of the assignor's commitment in case of insolvency of the debtor. ${ }^{36}$ There are two types of contractual clauses that may be included in the nonrecourse assignment agreements, namely credit limits and allowances. Credit limits represent the maximum factor's exposure with respect to the entire assigned portfolio, while allowances represent the minimum level of portfolio losses: below that level, the assignor is required to repay the factor.

The service offered by factoring companies may prove quite heterogeneous in relation to the clients' specific needs and, considering the various available financial instruments, it is quite hard to succeed in singling out the potential substitutes of this

and its potential in eastern Europe, World Bank working paper no. 3342.

32 Summers B. and Wilson N. (2000), "Trade credit management and the decision to use factoring: an empirical study", Journal of Business, Finance \& Accounting, vol. 27, pp. 37-68.

${ }^{33}$ Bakker M.R. and Gross A. (2004), Development of non-bank financial institutions and capital markets in the European Union accession countries, World Bank working paper no. 28.

${ }^{34}$ Udell G. (2004), Asset based finance, Commercial Finance Association, pp. 81-88.

${ }^{35}$ Fossati G. and Porro A. (1985), Il factoring, Giuffrè Editore, Milano, pp. 21-38.

${ }^{36}$ With reference to the regulations governing these clauses, which are unconscionable for the assignor, see Clarizia R. (2002), I contratti per il finanziamento dell'impresa. Mutuo di scopo, leasing e factoring, Giappichelli editore, Torino, pp. 417-558. 
service. In view of the above, the want of substitutes would seem to rule out the risk that a merger of a factoring company with a banking group might have a negative impact on the demand for services offered by different intermediaries. ${ }^{37}$ Besides, the decision to build up a very diversified portfolio of financial products permits to limit the overall risk for the group. ${ }^{38}$ Actually, the reduction of the profits yielded by a few products lines offered by affiliated intermediaries may be counterbalanced by the increase in profits reported in other sectors ${ }^{39}$ and the overall risk exposure connected with the cyclic nature of the various products and/or services proves lower. ${ }^{40}$

The analysis of the market dynamics of the main types of financing highlights a different level of complementarity of factoring schemes with respect to other products (graph 2). ${ }^{41}$

\footnotetext{
${ }^{37}$ Demattè et al. (1993), Economia degli intermediari finanziari, Egea, Milano, pp. 433-532.

${ }^{38}$ Boyd J.H. and Graham S.L. (1998), "The profitability and risk effects of allowing bank holding companies to merge with other financial firms: A simulation study", Federal Reserve Bank of Minneapolis Quarterly Review, vol. 12, pp. 3-20.

${ }^{39}$ Holmer M.R. and Zenios S.A. (1995), "The productivity of financial intermediation and the technology of financial product management", Operational Research, vol. 43, pp. 970-982.

${ }^{40}$ Reichert A.K. and Wall L.D. (2000), "The potential for portfolio diversification in financial services", Federal Reserve Bank of Atlanta Economic Review, vol. 85, pp. 35-51.

${ }^{41}$ Boczar G.E. (1976), Competition between banks and finance companies: a cross section study of personal loan debtors, CRC working paper.
} 


\section{Graph 2}

Yearly percentage variation in the supply of factoring and other financial services

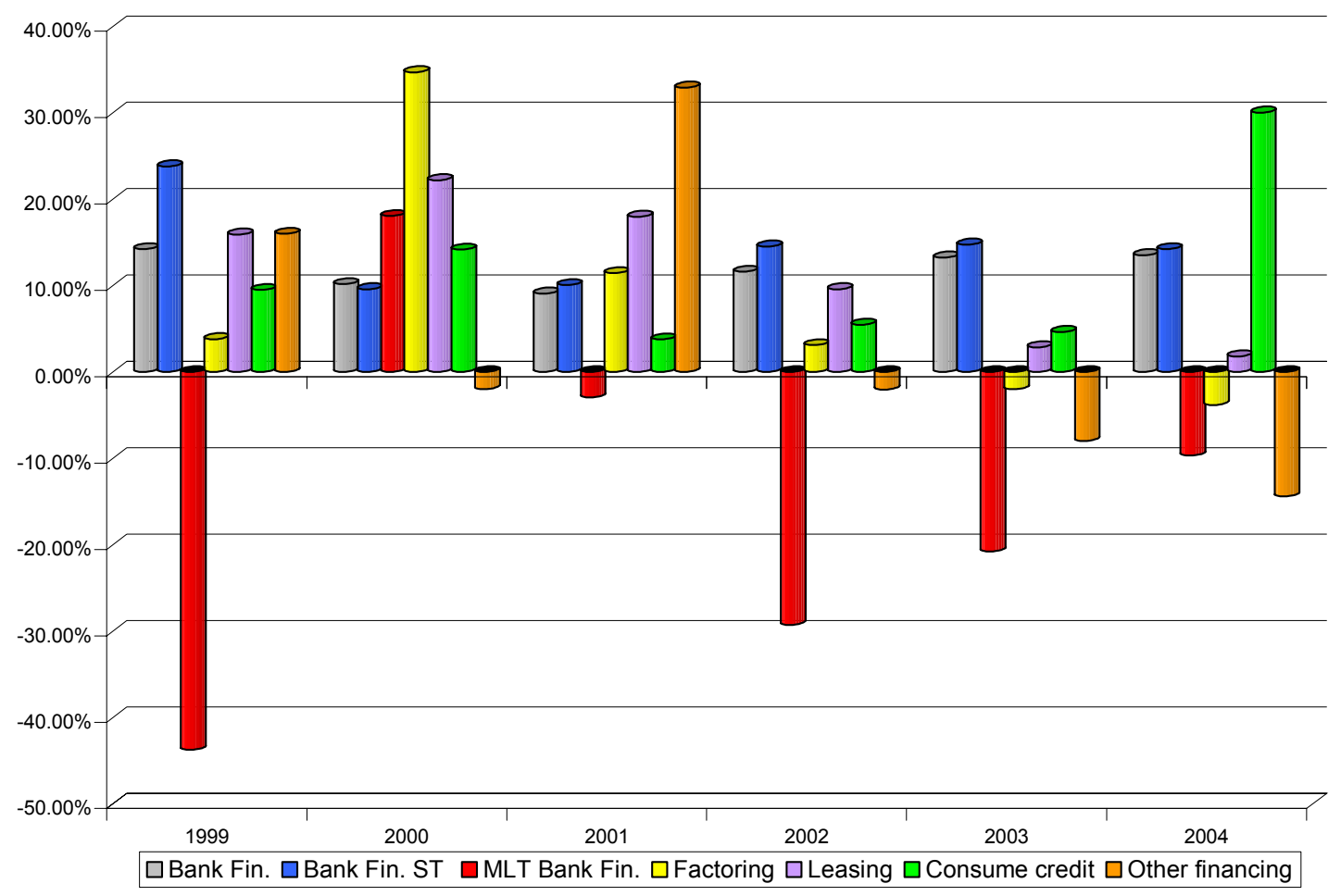

Source: Authors' processing of Bank of Italy data

As regards this subject, the trend of the factoring supply differs to a significant extent from that of other medium-long term financial instruments, with positive effects on the decrease of the risk for the group. ${ }^{42}$ A more exhaustive analysis may calculate the factoring elasticity with respect to other financial services granted by intermediaries (table 1). ${ }^{43}$

\footnotetext{
${ }^{42}$ Carey M. et al. (1998), "Does corporate lending by banks and finance companies differ? Evidence on specialization in private debt contracting", Journal of Finance, vol. 53, pp. 845-878.

${ }^{43}$ Schwizer P. (1984), "I modelli istituzionali e l'assetto organizzativo", in Ruozi R. and Carretta A. (edited by ), Manuale del leasing, Giuffrè, Milano.
} 
Table 1

Elasticity of the factoring service with respect to financial services

\begin{tabular}{|c|c|}
\hline \multicolumn{1}{|c|}{} & Elasticity \\
\hline \hline Banking services & -0.2748 \\
\hline Leasing & 1.2553 \\
\hline \hline Consumer credit & -0.8730 \\
\hline \hline Other financial instruments & 2.3531 \\
\hline
\end{tabular}

Source: Authors' processing of Bank of Italy data

Factoring features a considerably high level of replaceability with respect to consumer credit services and, although to a much lower extent, even with respect to bank loans. On the other hand, other services that a banking group may potentially decide to offer (leasing or other types of financial services) prove to be complementary with respect to the factoring activity.

In any event, the lack of any significant negative correlation between the supply of factoring services and the supply of other financial services makes it reasonable to state that the inclusion of the factoring business within the group offer may lead to an increase in the number of potential clients ${ }^{44}$ and an enhancement of the clients' loyalty through the supply of a more comprehensive series of services. ${ }^{45}$

The outcome of such an analysis should be considered merely approximate since the objective of increasing their clients is not the only aim pursued by intermediaries merging with a group. In fact, studies reported in the literature have stressed that financial margins have considerably different characteristics among different intermediaries and it is quite likely that the integration decisions are taken not only to maximize the volume of operations but also to stabilize the economic result attained over time. ${ }^{46}$

\footnotetext{
${ }^{44}$ Casu B. and Girardone C. (2004), "Financial conglomeration: efficiency, productivity and strategic drive", Applied Financial Economics, vol. 14, pp. 687-696.

${ }^{45}$ Gyongyi L. (2000), Financial conglomerates: innovation, scope economies and incentives, Birbek college working paper, London.

${ }^{46}$ Monferrà S. (1998), "Regolamentazione e intermediari finanziari non bancari: alcune evidenze sui differenti comportamenti aziendali", in Carretta A. (edited by), Banche e intermediari non bancari: concorrenza e regolamentazione, Bancaria Editrice, Roma.
} 


\subsection{The factoring productive process and potential intergroup synergies}

The variety and complexity of the services offered under the different types of agreement call for a breaking up of the factoring business - having recourse, for instance, to Porter's value chain approach - in relation to the link of the individual operations to the corporate core business. ${ }^{47}$ Therefore, the various activities may be classified as follows:

$>$ primary activities, which include the factoring productive process stages, from the acquisition of clients to the management of the relationship and any contentious business;

$>$ support activities, which represent the crosswise processes required to render the service, such as management of human and physical resources, administration and accounting, planning and auditing.

Graph 3 highlights the individual stages of the productive process and the main interrelations among the primary activities.

\section{Graph 3}

The chain value of the factoring activity

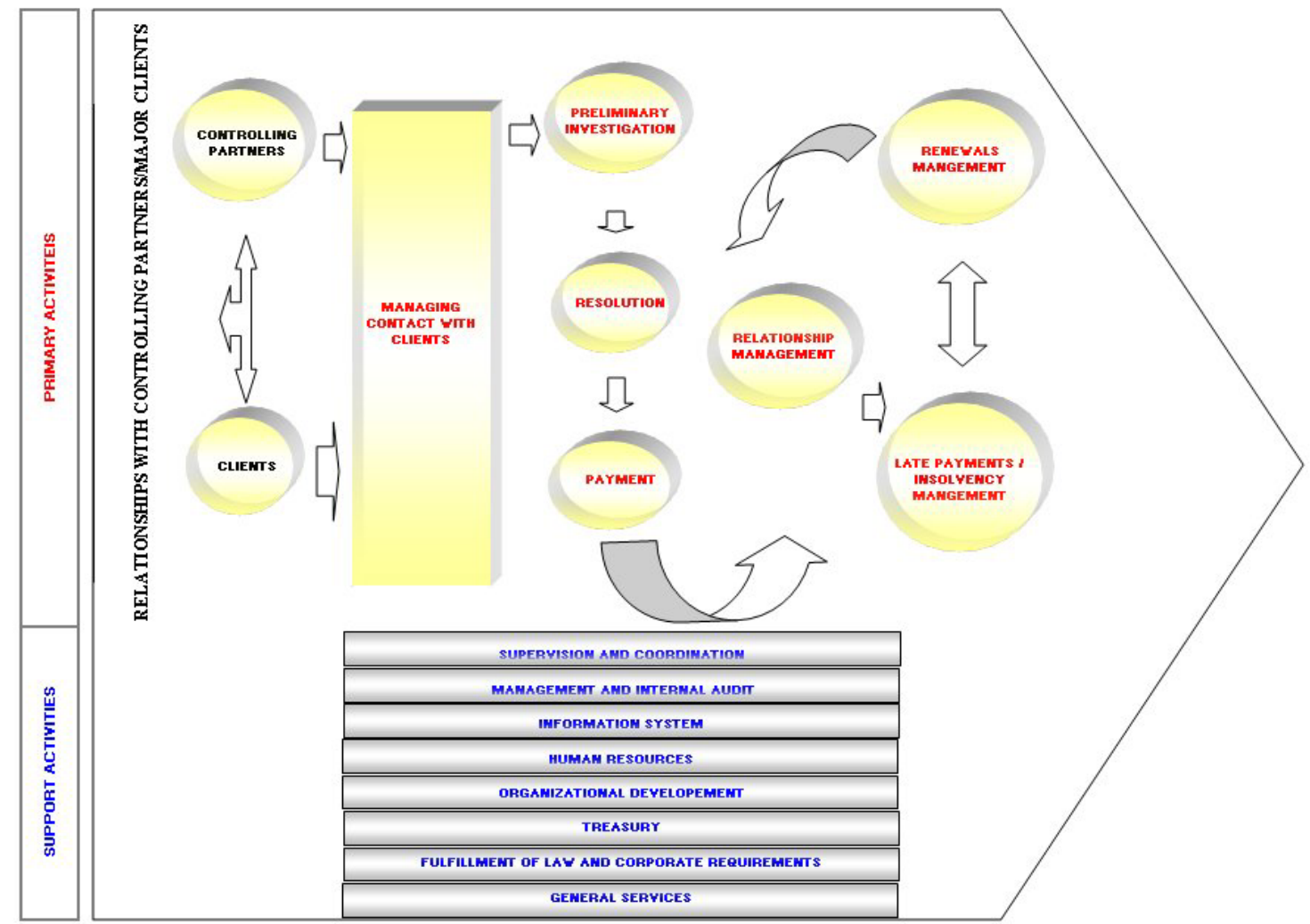

Source: authors' elaboration

${ }^{47}$ Porter M. (1987), Il vantaggio competitivo, Edizioni Comunità, Milano. 


\subsubsection{Primary activities}

The management of the relationships with the controlling partners is a stage that calls for a review of the objectives pursued by those who have the control of the enterprise with a view to determining guidelines that are consistent with the expectations of the ownership. An excessive shareholders' spread and the want of a clear corporate leadership may make it hard to plan the corporate activity ${ }^{48}$ and, as a result, it seems unlikely that enterprises lacking a strong control, with respect to the average for the sector they belong to, might succeed in reporting a good performance. ${ }^{49}$

The stage of the contact with the client requires the identification of the best channels to provide the service, and it is quite likely that the different segments of prospective clients require to be handled having recourse to different contacts. ${ }^{50}$ The assignor who turns to a factoring company is usually a company with a commercial credit portfolio that is not meager and it is not likely that the factor will need to invest resources in the setting up of a wide network of contacts. Therefore, the intermediary's objective is not the creation of an all-pervading distribution system but it is merely to single out the contact channel that allows meeting the client's requirements in the most comprehensive manner. As a rule, the selected approach tends to privilege the physical rather than the telematic channel.

The evaluation of the counterparties may be broken down into three stages: preliminary investigation, decision and payment. The preliminary investigation is carried out directly by the intermediary's front office. The decision stage provides for the approval by the top ranking corporate officers. The payment stage involves different intermediary's functions who are to bring into effect the decisions taken in the preceding stage. While the decision and payment stages have no peculiar features with respect to the same stages carried out by other financial intermediaries, the preliminary investigation stage entails an approach that differs to a significant extent from the one adopted by the other financial intermediaries. In fact, the analysis of clients is not restricted to those who require the factoring service (assignors) but also to those who are indirectly involved in the relationship (assigned debtors). Therefore, in assessing the operation, one needs to take into consideration not only the characteristics of the assignor but also those of the other persons involved, such as debtors and guarantors, if any, and the weight to be attached to the different persons involved will depend on the characteristics of the agreement that is entered into. In the case of non-recourse assignments, the factor needs to consider for the most part the characteristics of the assigned person and the guarantor, if any, while in the recourse assignments he needs to give more thorough consideration to the characteristics of the assigning firm since,

\footnotetext{
${ }^{48}$ Schleifer A. and Vishny R. (1995), A survey of corporate governance, NBER working paper no. 5554, Cambridge.

49 Becht M. et al. (2002), Corporate governance and control, NBER working paper no. 9371, Cambridge.

${ }^{50}$ Peppard J. (2000), “Customer Relationship Management (CRM) in financial services", European Management Journal, vol. 18, pp. 312-327.
} 
particularly when dealing with a non-notification assignment, the outcome of the operation may depend to a considerable extent on the latter. ${ }^{51}$

The agreement is entered into in a subsequent phase, further to the formalization of the relationships between the factoring company and the assignors, as well as with all the assigned debtors if the assignment provides for a direct relationship with the latter. All the administrative requirements are fulfilled at this time, and the assignor is issued the credit limit relative to the assigned receivables calculated based on the characteristics of the assigned debtors' portfolio and the type of agreements being entered into. ${ }^{52}$

The management of the relationship identifies the standard operations linked to the drawing up of the agreement with the assignor, starting from the acquisition phase down to the account receivable assignment phase. The criticalities that may crop up are related to the management of collections and/or due dates, invoicing of the amounts, notification, if any, to debtors and a likely revision of the agreement. ${ }^{53}$

The terms of the factoring agreement may be revised during the life of the relationship further to changing requirements and means of the assigned debtors and/or the assignor. The renewal and decision revision management phases represent a crucial time to limit the risk of a total loss in case of difficulties of either the assigner or the debtor and, just as in the case of trade credits in general, a successful management of these procedures may considerably limit the losses linked to the factoring activity. ${ }^{54}$

The management of bad debt business represents a significant activity for a factoring company. ${ }^{55}$ A proper management of insolvent parties may cut down to a considerable extent the intermediary's losses linked to acquired accounts receivables, particularly when backed up by collateral, since the starting of debt recovery procedures allows a fundamental reduction in the exposure upon default. ${ }^{56}$

\subsubsection{Support activities}

The supervision and coordination function allows a standardization of the behavior of all the parties working within the enterprise and represents a relevant aspect in factoring companies owing to the high heterogeneity of the services rendered and the

\footnotetext{
${ }^{51}$ Ruozi R. and Rossignoli B. (1985), Manuale del factoring, Giuffrè Editore, Milano, pp. 31-78.

52 Sopranzetti B.J. (1998), "The economics of factoring accounts receivables", Journal of Economics and Business, vol. 50, pp. 339-359.

${ }^{53}$ Richardson D. (1993), “A factor in your future”, Engineering Management Journal, vol. 3, pp. 278280.

54 Thorburn K.S. (2000), "Bankruptcy auctions: costs, debt recovery and firm survival", Journal of Financial Economics, vol. 58, pp. 337-368.

${ }^{55}$ Peel M.J. et al. (1999), Late payment and credit management in the small firm sector: some empirical evidence, CMRC working paper, Leeds.

56 Araten M. et al. (2004), "Measuring LGD on commercial loans: an 18-years internal study", $R M A$ Journal, vol. 86, pp. 96-103.
} 
competences that characterize the individual corporate actors. ${ }^{57}$ The relevance of this function increases as the size of the enterprise and the complexity of the relationships established among the parties participating in the business increase.

The proper operation of a factoring company is ensured by the presence of a management and internal audit function that succeeds in evaluating the propriety of the individual processes being implemented and in deciding the inner allocation of resources in relation to both the ability of the individual profit centers to create value and the objectives to be attained by the enterprise. ${ }^{58}$

The corporate information system allows the proper generation and handling of data flows within the enterprise and the enhancement of the wealth of information available to the factoring company. The definition of an efficient system represents a sound decision-making support since internal data - particularly when dealing with smallsized counterparties ${ }^{59}$ - are one of the major sources used in the process for evaluating clients. ${ }^{60}$ Given the high incidence of fixed costs for the setting up of the required structure, significant scale economies for the banking groups may be identified in that context. ${ }^{61}$

The survival of a factoring company may not be ensured without a proper management of the available human resources. Just as in any other corporate context, the objectives pursued by that function are the maximization of the contribution of each individual to the attainment of the objectives pursued by the enterprise as well as the optimum use of the distinctive expertise of the resources within the enterprise. ${ }^{62}$

The proper management of the available resources is closely linked to the presence within the enterprise of a structure suitable for the attainment of the objectives being pursued and is subordinated to the ability to manage those changes of the inner organizational structure that are required to adjust it to the evolution of the context. The evolution of the organizational structure must take into account not only changes on the outside of the enterprise, but also changes within the enterprise resulting from the availability of new physical or human resources, seeing to the definition of new internal setups that keep such changes into account. ${ }^{63}$

\footnotetext{
${ }^{57}$ Hillyer W.H. (1939), "Four centuries of factoring”, Quarterly Journal of Economics, vol. 53, pp. 305311.

${ }^{58}$ Paape L. et al. (2003), "The relationship between internal audit function and corporate governance in the EU - A survey", International Journal of Auditing, vol. 7, pp. 247-262.

${ }^{59}$ Berger A.N. and Udell G.F. (1995), "Relationship lending and lines of credit in small firm finance", Journal of Business, vol. 68, pp. 351-381.

${ }^{60}$ Eslyn L.J.B. (2005), "Information monopoly and commitment in intermediary-firm relationships", Journal of Financial Services Research, vol. 27, pp. 5-26.

${ }^{61}$ Baravelli M. (2003), Strategia e organizzazione della banca, Egea, Milano, pp. 61-87.

${ }^{62}$ Boudreau J.W. and Ramstad P.M. (2005), "Talentship, talent segmentation and sustainability A new HR decision science paradigm for a new strategy definition”, Human Resource Management, vol. 44, pp. 129-136.

${ }^{63}$ Lei D. et al. (1999), "Designing organization for competitive advantage: the power of unlearning and learning”, Organizational Dynamics, vol. 27, pp. 24-38.
} 
The attainment of the objectives pursued by the company requires a proper allocation of the available resources with a view to maximizing the worth of the enterprise and enhancing the profit centers. ${ }^{64}$ In factoring companies, the treasury management does not allow the possibility of using any resource surplus to implement operations having no bearing on the factoring activity, but a proper management of the available resources and a planning of financial requirements represent relevant aspects even for these intermediaries.

The existence of a factoring company gives rise to the need to comply with the legal and administrative requirements provided for that activity and, even if those tasks create no value for the company, the failure to comply with those regulations may prevent the attainment of the corporate objectives being pursued. The objective pursued by the intermediary in those activities may be identified in the search for scale economies allowing the intermediary to minimize the impact of the cost components that may not be done away with. ${ }^{65}$

${ }^{64}$ Inselbag I. (1973), "Financing decisions and the theory of the firm", Journal of Financial and Quantitative Analysis, vol. 8, pp. 763-776.

${ }_{65}$ Forestieri G. and Mottura P. (2004), Il sistema finanziario. Istituzioni, mercati e modelli di intermediazione, Egea, Milano, pp. 300-303. 


\subsubsection{The ambits of differentiation and integration with respect to the traditional credit activity}

The complex productive process that characterizes the provision of the factoring service lays emphasis on the strong potential synergies with other intermediaries of the group in respect of both the primary and the support activities resulting from the adoption of the organizational structure of the group. These synergies are structurally linked to the efficient governance of the interdependences between factoring-related processes and processes peculiar to other financial services. Based on their peculiar nature, they may be classified as follows: ${ }^{66}$

$>$ sequential synergies, whenever the provision of the service by an intermediary gives rise to the possibility for other members of the groups to provide additional services;

mutual synergies, that arise when symmetric exchanges of resources and/or information occur within the group;

generic synergies, resulting from the possibility of using common resources, minimizing the share of fixed costs weighing on the individual services being provided.

In view of the above, the different phases of the productive process of a factoring company may be classified based on the intensity of the benefits resulting from the merger into the group and on the type of interdependence existing with the subjects belonging to the group.

Table 2

Level of synergies within the financial group for the various activities

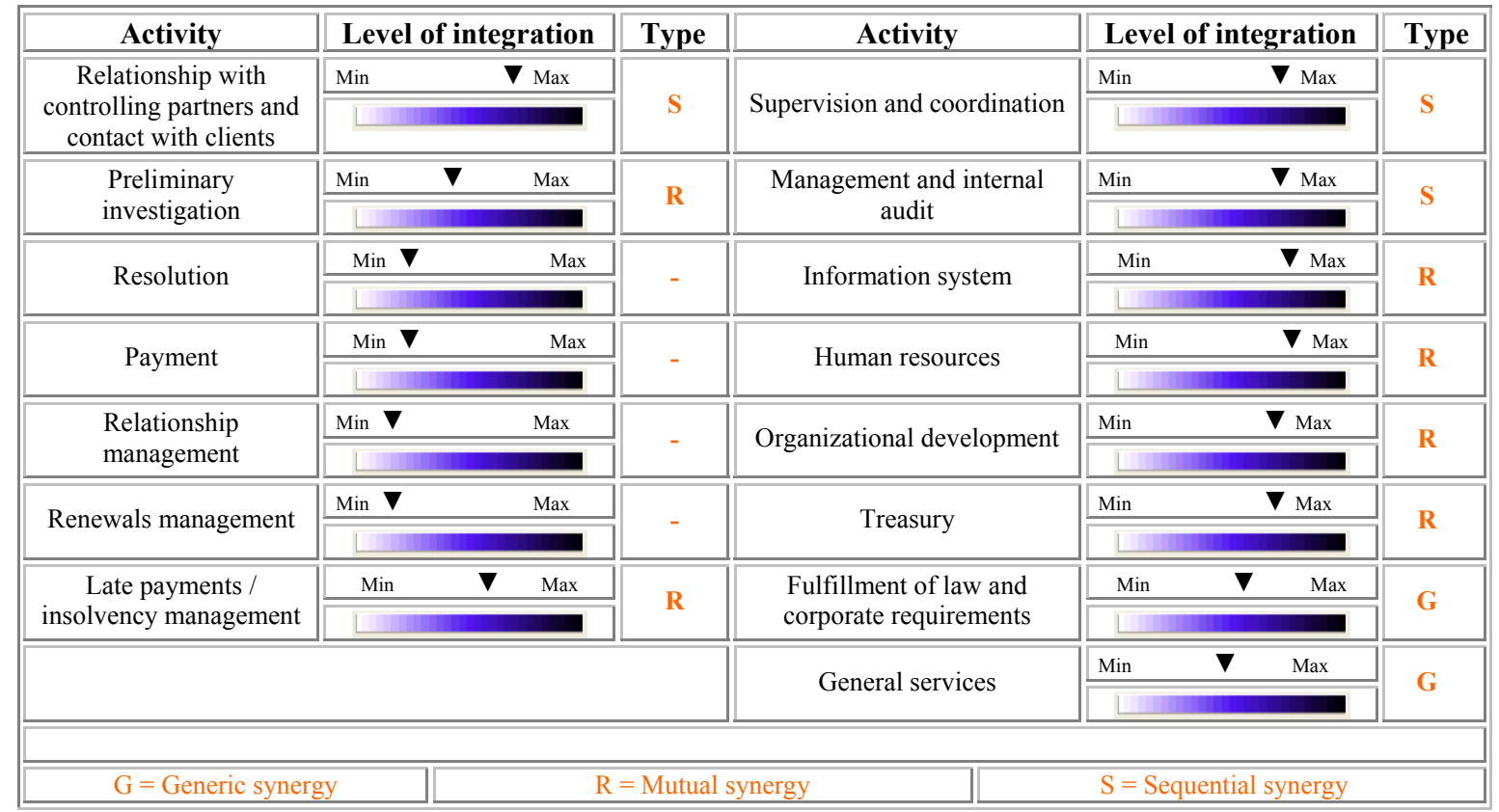

Source: Authors' elaboration

${ }^{66}$ Thompson J.D. (1967), Corporate in Action, Mc Graw Hill, New York. 
In the phase of contact with the client, the participation in the group affords the opportunity of increasing prospective clients, ${ }^{67}$ since the intermediary may offer services even to the clients of other connected intermediaries. Besides, the possibility of using the same distribution network and of obtaining benefits resulting from the recourse to the group brand may ensure significant advantages to all the group members, ${ }^{68}$ particularly in the financial intermediation sector where the immaterial component of the services rendered to clients turns the reputation of the business into a fundamental asset. ${ }^{69}$

Furthermore, the decision to admit a factor within a banking group may make the evaluation of prospective clients easier if the shared clients represent a significant part of the corporate portfolio of clients since the information collected by the others members may be used to limit the problem of the informative asymmetry that may characterize the factor-client relationship. ${ }^{70}$ Nonetheless, in the face of this advantage there are a few constraints for the members of the group who, most likely, may not use different evaluation methodologies for clients (borrower rating) and have the opportunity to differentiating their judgment merely on the basis of the peculiar characteristics of the individual operations (facility rating).

In the collection management phase and, in particular, while managing contentious business, the fact of belonging to a group may give rise to a few advantages. For instance, legal costs may be decreased if the relationships with external lawyers are centralized or coordinated by the parent company in order to wield a greater contracting power and obtain improved economic conditions.

The corporate information system may be developed and handled directly by the parent company based on information provided by the factoring company in order to minimize the overall costs involved in setting up the database. ${ }^{71}$ In any event, this may give rise to a few problems related to the flexibility of the system and the limited personalization of the system and, therefore, of the electronic procedures with respect to the characteristics of the factor's processes.

The centralized or, anyway, coordinated management of the personnel policies within the group allows an enhancement of the expertise of the individual persons, leading to the definition of more comprehensive career courses.

As for the treasury, it may prove reasonable to delegate the provision of a few common services to a single subject in the group in order to avoid useless and costly duplications

\footnotetext{
${ }^{67}$ Mariti P. and Smiley R.H. (1983), “Cooperative agreements and the organization of industry”, Journal of Industrial Economics, vol. 31, pp. 437-451.

${ }_{68}^{68}$ Corvi E. (1989), Il gruppo nell'economia dell'azienda industriale, Egea, Milano, pp. 131-178.

69 Whalen G. (1997), Bank organization form and the risks of expanded activities, OCC Economics Working Paper.

${ }^{70}$ De Angeli S. (1995), "Il processo di trasformazione dell'industria bancaria", in Scott W., Manuale di marketing bancario, Utet, Torino.

${ }^{71}$ Lang G. and Welzel P. (1998), “Technology and cost efficiency in universal banking. A 'thick' frontier. Analysis of German banking industry”, Journal of Productivity Analysis, vol. 10, pp. 63-84.
} 
of the resources devoted to the supply of similar services and allow an improved allocation of resources within the group. ${ }^{72}$ Moreover, the increase in volume of the operations to be managed by this subject determines an increase in costs that is lower than a proportional increase and, at a group level, this allows making the most of significant economies of scale in the provision of those services. ${ }^{73}$ Finally, further advantages for the treasury management may originate from the existence of a preferential funding channel of the factoring company - represented by the parent company and other banks of the group - that may turn into an advantage in terms of fund availability and cost and, in the final analysis, may make it easier for the factoring company to handle difficulties, if any.

The centralization of part of the general services and compliance may allow a rationalization of the cost structure and give rise to significant economies, even in terms of experience, at a group level. ${ }^{74}$

\subsection{Evaluation of the relationships among the group members}

The inner structure and the typical behavior of factoring companies differ from the standards adopted by other financial intermediaries ${ }^{75}$ and the analysis of the suitability of a group structure may not be performed without taking into account the problems, if any, resulting from difficulties in the interaction among organizations having a different structure. $^{76}$ Indeed, the creation of a network of enterprises presupposes the management of the process of integration of the various organizational units and as the differentiation of the individual units grows, there is an increase in the burden connected with the integration process. ${ }^{77}$ In fact, the scarce compatibility of the subjects involved and/or of the inner processes that characterize them may reduce the advantages resulting from this organizational setup since it may give rise to structural constraints that prevent the group from making the most of its synergies. ${ }^{78}$

Therefore, the analysis of the group impact on the participating companies must take into consideration the repercussions of that structure on the intercorporate relationships between the parent company and the controlled companies and among the individual members of the group and, if at all possible, the different organizational units and/or

\footnotetext{
72 Bertinetti G. (2004), "La finanza dei gruppi aziendali” in Dallocchio M. and Salvi A., Finanza d'azienda, Egea, Milano, pp. 603-820.

73 Anderson M.C. et al. (2003), “Are selling, general and administrative costs 'sticky'?", Journal of Accounting Research, vol. 41, pp. 47-63.

${ }^{74}$ Schwizer P. (1996), La diversificazione bancaria, Egea, Milano, pp. 81-102.

${ }^{75}$ Carretta A. (1991), "Un confronto tra banche e istituzioni finanziarie non bancarie", in Carretta A. (edited by), Le istituzioni finanziarie non bancarie, Egea, Milano.

${ }^{76}$ Williamson O.E. (1981), "The economics of organization: the transaction cost approach", American Journal of Sociology, vol. 87, pp. 548-577.

77 Previati D. (1995), "Gli assetti organizzativi delle banche", in Scott W., Manuale di marketing bancario, Utet, Torino.

${ }^{78}$ Jehn K.A. (1997), “A qualitative analysis of conflict types and dimension in organizational groups", Administrative Science Quarterly, vol. 42, pp. 530-557.
} 
tasks of the intermediaries. ${ }^{79}$ Nonetheless, the evaluation of the effectiveness of the adopted organizational structure must focus merely on the synergic interdependencies and remove from the analysis all those relationships that are established within the group but are unlikely to create value for participants.

The evaluation of the most guarded interdependencies may be carried out by borrowing a few approaches proposed by the social network analysis and considering both the interactions among subjects belonging to the different enterprises of the group and the exchanges that have taken place in terms of goods/services and/or information. ${ }^{80}$

The paragraph below proposes of a model of analysis of the characteristics of the group in contexts marked by uncertainty that permits to establish the optimum level of control by the parent company and to evaluate the suitability of the exchanges among the group members. Having defined the general guidelines, a few approaches - ingrained in the social network analysis studies ${ }^{81}$ - are singled out as they may be used to measure and monitor the level of control of the parent company and the level of interaction among the members of the group. The last paragraph is devoted to the presentation of a simplified model of analysis allowing the application of the social network analysis principles to the evaluation of the factor's role in banking groups.

\subsubsection{Managing relationships between parent company and controlled intermediaries}

The study of the level of interference of the parent company in the management of its controlled financial intermediaries, including factoring companies, may be conducted taking into consideration the exchanges of information flows within the group with a view to identifying the subjects who carry out policy-making and/or coordination functions. ${ }^{82}$ Given the variety of exchange flows within a group, ${ }^{83}$ the study must focus on the exchanges of information in order to ascertain whether a subject participates in the major decision-making processes and, therefore, may actually affect the outcome of those processes and exert a control over the decisions of the group. ${ }^{84}$ The measures suggested by the relevant literature for determining the relevance of the individual group actors analyze the number of relationships established by the parent company

\footnotetext{
79 Schwizer P. (1998), "Le politiche del personale: elementi di differenziazione e di integrazione", in Airoldi et al, La gestione del personale nei gruppi bancari. Strategia e pianificazione organizzativa, Bancaria Editrice, Milano.

${ }^{80}$ Zach M.H. (2000), "Researching organizational system using social network analysis", Proceedings of $33^{\text {rd }}$ International Conference on System Sciences, Maui, Hawaii.

${ }^{81}$ De Canio S. et al. (2000), "The importance of organizational structure for the adoption of innovations", Management Science, vol. 46, pp. 1285-1299.

${ }^{82}$ Zemljic B. and Hlebec V. (2005), Reliability of measures of centrality and prominence", Social Networks, vol. 27, pp. 73-88.

${ }^{83}$ For a more comprehensive classification of the various exchange flows that may occur within a network, see Borgatti S.P. (2005), "Centrality and network flows", Social Networks, vol. 27, pp. 55-71.

${ }^{84}$ Freeman L.C. (1977), “A set of measures of centrality based on betweenness”, Sociometry, vol. 40, pp. $35-41$.
} 
either directly or indirectly with the other members of the group. These measures may be broken down into a number of macro-categories: ${ }^{85}$

$>$ subject centrality indexes;

$>$ measures of the level of proximity to decision-making centers:

$>$ indicators of the level of centrality with respect to decisions taken in the group;

$>$ level of prestige and reputation of the subject.

The relevance within a group may be measured by considering the number of relationships established by a subject with the other group members, since the higher the number of subjects one is connected with, the higher the likelihood that the subject will succeed in influencing the decisions of the group, as expressed in the formula:

$$
\mathbf{C}=\sum_{i=1}^{n} n_{i}
$$

where the value of the indicator is merely given by the sum of the relationships $\left(n_{i}\right)$ established with the $n$ subjects in the group. ${ }^{86}$ As a rule, the measures of centrality are standardized with respect to the maximum number of relationships that may be established with the various subjects, so as to obtain easy-to-read indicators.

The decision-making processes in a group may be more or less complex, and the probability that an individual group participant might be involved in the decisions increases with the number of subjects involved in the decision-making process. Furthermore, the increase in the number of subjects involved results in a decrease in the relative weight of the subject within the group and, with a view to obtaining a measure of the relevance of the subject within the group, it may be necessary to filter the analysis having recourse to weighted measures for the length of the decision-making processes. ${ }^{87}$ These approaches may be formalized as follows:

$$
\mathbf{C}_{\mathbf{C}}=\sum_{i=1}^{n} \sum_{j=1}^{n} d\left(n_{i}, n_{j}\right)
$$

where the estimate of the subjects' centrality is given by the summation of the distances among the decision centers in the processes where the subject is involved $\left(d\left(n_{i}, n_{j}\right)\right)$.

In complex situations, the decision-making process proves as a rule complex, and involves for a variety of reasons a high number of subjects. In those contexts, the relevance within the group is not measured by the number of relationships that have been established, as it is given by the capacity to participate in the highest number of

\footnotetext{
${ }^{85}$ Freeman L.C. (1979), “Centrality in social networks: conceptual clarification”, Social Networks, vol. 1, pp. 215-239.

${ }^{86}$ Bavelas A. (1948), “A mathematical model for group structure”, Human organization, vol. 7, pp. 1630 .

${ }^{87}$ Bavelas A. (1950), "Communication patterns in task-oriented groups", Journal of the Acoustical Society of America, vol. 22, pp. 271-282
} 
decisions taken by the enterprise ${ }^{88}$ The indicators used to evaluate such a profile are probability indicators, such as:

$$
\mathbf{C}_{\mathbf{B}}=\sum_{i=1}^{m} p\left(r_{i}\right)
$$

where the relevance of the subject within the group is calculated as the summation of the probabilities for a subject to be involved in the $m$ decision-making processes of the group $\left(r_{i}\right)$.

The relevance within a group may be hardly noticeable, being linked not only to the actual interaction of the subject with the other members of the group, but also to the reputation it has gained over time. With a view to evaluating these qualitative profiles, the approaches proposed in the literature provide for the recourse to questionnaires conceived in such a way as to succeed in bringing out the opinions on the individual subjects belonging to the group. ${ }^{89}$

All the proposed measures represent an expedient tool to probe into the inner hierarchy of the group, but an improved performance may be obtained having also recourse to information about the nature of the informative exchanges and the subject who took the decisions in the individual exchanges. The use of such information allows the construction of directional indicators to evaluate with a lower margin of error the actual influence of the parent company on the decisions of individual members. ${ }^{90}$

The presence of a considerable centrality of the parent company identifies a scenario where the decisions of the group members are not independent and the parent company does not allow the participating firms the autonomy needed to make the best possible use of their distinctive expertise. An excessive influence of the parent company in the decisions of the individual enterprises is a drawback, particularly in very heterogeneous groups such as financial conglomerates, where members may only succeed in enhancing their distinctive competences if they enjoy a good level of autonomy. ${ }^{91}$

\subsubsection{Relationships among intermediaries belonging to a group}

In order to assess the impact of the creation of a group on the participating firms it becomes necessary to consider the level of interaction among the subjects that belong to the different enterprises that merged into the group. ${ }^{92}$ The ascertainment of scarce

\footnotetext{
${ }^{88}$ Pitts F.R. (1979), “The medieval river trade network of Russia revisited”, Social Networks, vol. 1, pp. 285-292.

${ }^{89}$ Alexander C.N. (1963), “A method of processing sociometric data”, Sociometry, vol. 26, pp. 268-269.

${ }^{90}$ For a review of the indicators being proposed, see Wasserman S. and Faust K. (1994), Social network analysis, Cambridge University Press, Cambridge, pp. 169-219.

${ }^{91}$ Grandori A. and Soda G. (2004), "Governing with multiple principals: an empirically-based analysis of capital providers' preferences and superior governance structures”, in Gradori A. (2004), Corporate governance and firm organization, Oxford University Press, New York.

${ }_{92}$ Economides N. (1996), “The economics of network", International Journal of Industrial Organization,
} 
relationships among subjects belonging to different companies or the want of a mechanism for coordinating the decisions taken by the various members of a group does not allow making the most of the benefits resulting from the adoption of that institutional model and identifies the scenarios where the adoption of that structure is not the best organizational solution.

Indeed, the effectiveness of a group depends on the efficiency of information sharing and the establishment of a network of relationships that allows members to allocate the available resources in the best possible manner. ${ }^{93}$ However, if there are no efficient connections among the various subjects in the transmission of information to other group members, such a structure forfeits the benefits linked to its flexibility and ability to adjust to changing contexts. ${ }^{94}$ Then again, the want of exchanges within the group prevents a proper allocation of the available resources and diminishes the benefits resulting from the synergies among members of the group. ${ }^{95}$

The actual interrelationship among subjects belonging to different enterprises within the group may be evaluated taking into consideration the information exchanges among the subjects of the group with respect to those made with external subjects. In fact, the creation of a network of enterprises presupposes the need or profitability of exchanges among members and the presence of a considerable volume of exchanges may be taken as a sign of the proper operation of the group. The indicators suggested in the literature in order to analyze this profile take into account the average number of exchanges made among group members and compare it with the average number of exchanges made with external subjects. ${ }^{96}$

This is expressed by the formula:

$$
C S=\frac{\sum_{i=1}^{n} n_{i}}{\sum_{j=1}^{m} m_{i}}
$$

where the level of cohesion (CS) is calculated as the ratio of the number of exchanges within the group $\left(\sum_{i=1}^{n} n_{i}\right)$ with respect to the volume of exchanges implemented by members of group with external entities $\left(\sum_{i=1}^{m} m_{i}\right)$.

vol. 14, pp. 673-699.

${ }^{93[93]}$ Van de Ven A.H. (1976), "A framework of organization assessment", Academy of Management Review, vol. 1, pp. 64-78.

${ }^{94}$ Newman M.E.J. (2005), "A measure of betweeness centrality based on random walks", Social Networks, vol. 27, pp. 39-54.

${ }^{95}$ Chung A.S. (1996), "Performance effects of cooperative strategies among investment banking firms: a loglinear analysis of organizational exchange networks", Social Networks, vol. 18, pp. 121-148.

${ }^{96}$ Bock R.D. and Husain S.Z. (1952), "An adaptation of Holzinger's B-coefficients for the analysis of sociometric data", Sociometry, vol. 15, pp. 206-219. 
On the other hand, different studies reported in the literature suggest that, rather than considering the volume of exchanges, one should analyze the probability of exchanges, and identify cohering groups comparing that value with the probability of making exchanges with the outside. ${ }^{97}$

Unlike the indicators proposed to identify the level of control, the measures suggested to assess the effectiveness of the group structure are calculated on a relative basis and univocal criteria may be singled out in order to interpret the indications they supply. Values below the unit point to situations where there are no relevant benefits linked to the setting up of the group and where it is most likely that the adoption of that structure does not stand to reason. ${ }^{98}$

Besides, more detailed studies of the characteristics of the group permit to highlight the types of connections existing among the members and to evaluate the ability of each individual participating intermediary to make the most of the benefits liked to the group. The analysis of this profile allows the identification of four categories of subjects: ${ }^{99}$

$>$ poorly integrated subjects that do not benefit from their association with the group;

$>$ subjects who are unilaterally linked only to a few subjects and have with them a limited number of exchanges;

$>$ subjects who are linked by many bilateral relationships with a high number of subjects within the group;

$>$ subjects linked by bijective relationships who maximize the results coming from the network because they have frequent direct exchanges with a few subjects in the group and are highly integrated with them.

The intermediaries who have a high number of exchanges with other members of the group reap greater benefits from their group membership, but the lack of concentration of the exchanges with a limited set of subjects may point to a situation where the inner exchange processes are too disjointed and there is no efficient management of the exchanges within the group. ${ }^{100}$ The possibility to single out the most relevant bijective relationships allows a redefinition of the organizational setup excluding from the group the poorly integrated subject or steering those subjects towards alternative solutions that might allow them to exploit the benefits linked to the group.

The analyses relative to the exchanges of goods or services among the different subjects prove more complex owing to the need to value the exchanges made among the various subjects moving from an approach based on the exchange frequency to a methodology

\footnotetext{
97 Alba R.D. (1973), "A graph theoretic definition of a sociometric clique”, Journal of Mathematical Sociology, vol. 3, pp. 113-126.

98 Granovetter M.S. (1973), “The strength of weak ties”, American Journal of Sociology, vol. 78, pp. $1360-1380$.

${ }^{99}$ Peay E.R. (1980), “Connectedness in a general model for valued networks”, Social Networks, vol. 2, pp. 385-410.

${ }^{100}$ Ahuja G. (2000), "Collaboration networks, structural holes and innovation: a longitudinal study", Administrative Science Quarterly, vol. 45, pp. 425-455.
} 
based on the intensity and the value of the relationship. ${ }^{101}$ The definition of the equivalent value of the exchanges proves complex particularly in very integrated entities such as groups, and the quantification of the exchanges among financial intermediaries is particularly relevant since the level of immateriality of the good/service being exchanged is high. Nonetheless, the analysis of this profile becomes extremely relevant particularly when evaluating the integration existing among a few functions, such as the treasury, where the effectiveness of the integrated management may be measured only when the value of the exchanges that have been made is known.

The evaluation of the group impact may become even more complex in the presence of a variety of relationships and exchanges that are not formalized within the group and that are not easily identifiable by a subject outside the enterprise. In any event, a study of the relationships existing within a group may not neglect the informal relationships, since studies dealing with a variety of industrial situations have highlighted the considerable relevance of this type of relationships within the enterprise ${ }^{102}$ as well as with outside enterprises. ${ }^{103}$

Finally, the study of the intragroup relationships needs to consider the reasons, if any, of scarce interrelationships among the subjects of a group and evaluate whether such reasons may be referred to the incompatibility of the businesses involved - too far apart in terms of expertise, competence and characteristics of the individual intermediaries -, or simply to differences in the inner organizational procedures of each individual business. ${ }^{104}$ The presence of differences in the inner processes of the group members may limit the capacity to communicate and to exchange resources ${ }^{105}$ and, therefore, limit the possibility of maximizing the benefits resulting from intragroup synergies. ${ }^{106}$ In the case of banking groups, significant differences may be ascertained in the overall inner processes linked to differences in the products/services offered to clients by the individual intermediaries, but it is nonetheless necessary that homogeneous procedures be defined for the individual phases that are subject to integration. In fact, the standardization of these phases allows reducing the cost of the inner coordination procedures that are time consuming by nature, ${ }^{107}$ in addition to being likely to increase the capacity to create value through the setting up of the network.

\footnotetext{
${ }^{101}$ Yang S. and Knoke D. (2001), "Optimal connections, strength and distance in valued graphs", Social Networks, vol. 23, pp. 285-295.

102 Cross R. et al. (2002), Making invisible work visible: using social network analysis to support strategic collaboration, University of Virginia working paper.

${ }^{103}$ Williams M. (2003), Interpersonal action across organizational boundaries: threat and trust in the contest of social network diversity, MIT Sloan School of Management working paper, Cambridge.

${ }^{104}$ Milliken F.J. and Martins L.L. (1996), "Searching for common threads: understanding the multiple effects of diversity in organizational groups", Academy of Management Review, vol. 21, pp. 402-433.

105 Dougherty D. (1992), "Interpretative barriers for successful product innovation in large firms", Organization Science, vol. 3, pp. 179-202.

${ }^{106}$ Gladstein Ancona D. and Caldwell D.F. (1992), "Demography and design: predictors of new product team performance”, Organization Science, vol. 3, pp. 321-341.

107 Murray A.I. (1989), "Top management group heterogeneity and firm performance", Strategic Management Journal, vol. 10, pp. 125-141.
} 


\subsection{A model of analysis to evaluate the role of a factoring company within a group}

A review of the literature has stressed how the analysis of the factor's role in a banking group presupposes the study of the interaction arrangements within the group as well as the level of interaction in performing the individual corporate operations. In any event, when dealing with the more complex groups, it is hard to have access to detailed information about all the decision-making processes. This calls for the identification of a few proxies that prove useful for the representation of the economic relationships among the different companies making up the group. A few grids for the collection of data useful for the construction of these proxy variables are enclosed below.

Firstly, it should be considered that the analysis of the intragroup interactions must take into account the mechanisms of control/interference that may be present within a group and the role of the various subjects involved. In view of the above, an initial step is to delve into the instruments of direct control. An analysis of the corporate governance of the individual group units and, in particular, the composition of the administrative bodies (typically, the board of directors) of the individual companies and the respective management committees (credit committee, etc.), allows tracing the level of relevance in percentage terms of the representatives of the individual intermediaries within the group (Table 3$).^{108}$

${ }^{108}$ Beretta S. (1990), Il controllo dei gruppi aziendali, Egea, Milano, pp. 177-193. 
Table 3

Relevant information for the evaluation of administrative boards' and committees' composition

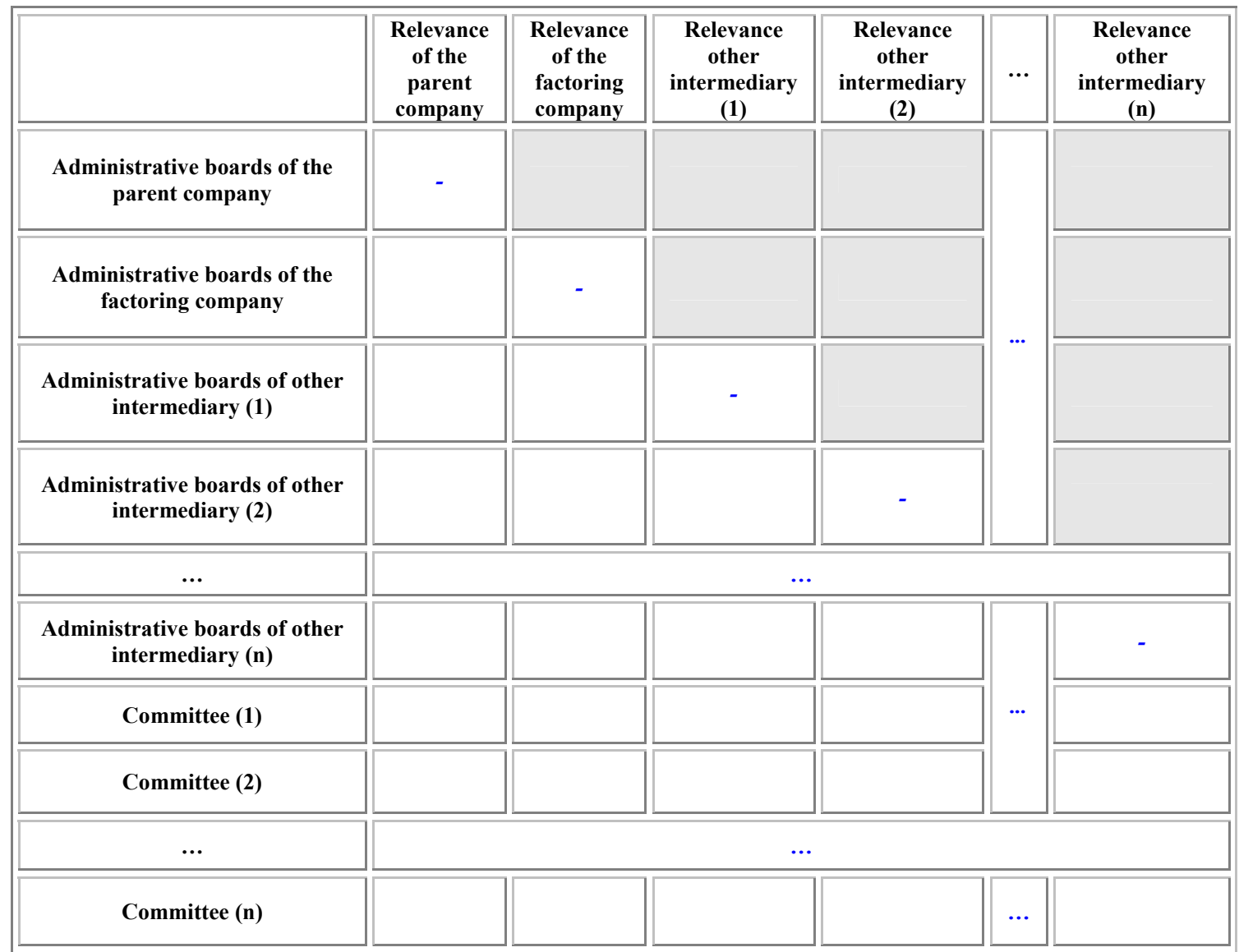

Secondly, with a view to obtaining a more comprehensive picture of the inner group relationships, even the so-called indirect control mechanisms have to be taken into consideration. ${ }^{109}$ The study of the financial flows and the exchanges of goods and services that occur within the group makes it possible to enhance the centrality of the individual intermediary and to identify the actual hierarchy existing within the group (table 4).

\footnotetext{
${ }^{109}$ Schwizer P. (1998), "I modelli di corporate governance negli intermediari finanziari ad azionariato diffuso", in Airoldi G. and Forestieri G., Corporate governance. Analisi e prospettive del caso italiano, Etas Libri, Milano, pp. 344-364.
} 
Table 4

Evaluation scheme for the study of intra-groups transactions

\begin{tabular}{|c|c|c|c|c|c|c|c|c|c|c|c|}
\hline & \multicolumn{2}{|c|}{ Parent company } & \multicolumn{2}{|c|}{ Factoring company } & \multicolumn{2}{|c|}{$\begin{array}{l}\text { Other financial } \\
\text { intermediary of the } \\
\text { group (1) }\end{array}$} & \multicolumn{2}{|c|}{$\begin{array}{l}\text { Other financial } \\
\text { intermediary of the } \\
\text { group (2) }\end{array}$} & & \multicolumn{2}{|c|}{$\begin{array}{c}\text { Other financial } \\
\text { intermediary of the } \\
\text { group (n) }\end{array}$} \\
\hline & $\begin{array}{l}\text { Value of } \\
\text { goods and } \\
\text { services } \\
\text { exchanged }\end{array}$ & $\begin{array}{c}\text { Net } \\
\text { financail } \\
\text { flows }\end{array}$ & $\begin{array}{l}\text { Value of } \\
\text { goods and } \\
\text { services } \\
\text { exchanged }\end{array}$ & $\begin{array}{l}\text { Net } \\
\text { financail } \\
\text { flows }\end{array}$ & $\begin{array}{l}\text { Value of } \\
\text { goods and } \\
\text { services } \\
\text { exchanged }\end{array}$ & $\begin{array}{l}\text { Net } \\
\text { financail } \\
\text { flows }\end{array}$ & $\begin{array}{l}\text { Value of } \\
\text { goods and } \\
\text { services } \\
\text { exchanged }\end{array}$ & $\begin{array}{c}\text { Net } \\
\text { financail } \\
\text { flows }\end{array}$ & & $\begin{array}{l}\text { Value of } \\
\text { goods and } \\
\text { services } \\
\text { exchanged }\end{array}$ & $\begin{array}{l}\text { Net } \\
\text { financail } \\
\text { flows }\end{array}$ \\
\hline Parent company & - & - & & & & & & & & & \\
\hline Factoring company & & & - & - & & & & & & & \\
\hline \multicolumn{12}{|l|}{$\begin{array}{l}\text { Other financial } \\
\text { intermediary of the group } \\
\text { (1) }\end{array}$} \\
\hline $\begin{array}{l}\text { Other financial } \\
\text { intermediary of the group } \\
\text { (2) }\end{array}$ & & & & & & & - & - & & & \\
\hline$\cdots$ & \multicolumn{8}{|c|}{$\cdots$} & & \multicolumn{2}{|c|}{$\ldots$} \\
\hline $\begin{array}{l}\text { Other financial } \\
\text { intermediary of the group } \\
\text { (n) }\end{array}$ & & & & & & & & & & - & - \\
\hline
\end{tabular}

Source: authors' elaboration

\section{CREDIFact}


Thirdly, the high heterogeneity of the primary and secondary activities carried on by the factor gives rise to a different capacity to take advantage of the benefits that come with joining a financial group. Therefore, this calls for a further inquiry into the benefits obtained by the factor in the individual activities being carried on (Table 5).

An analysis of the group impact needs first of all to consider to what extent the processes relative to an individual activity are outsourced. The assessment must be carried out in a differential perspective considering the likely alternatives ${ }^{110}$ and highlighting, merely in respect of the outsourced activities, the decisions taken in the selection of the counterparty to be involved in the outsourcing process. In fact, the failure to value the level of potential outsourcing that characterizes individual activities could end up jeopardizing all the activities that, owing to their intrinsic features, do not lend themselves to being outsourced. ${ }^{111}$

The factor's integration within the group must be assessed considering both the simple information flows and the material exchanges. As a result, the contact frequency must be dealt with separately from the numerousness of the transactions. Finally, with a view to getting to a comprehensive analysis of the relevance of the phenomenon for the individual function, it becomes necessary to probe into the dimensional characteristics of that function (measured, for instance, by the number of resources being used) and to use these information to standardize data in order to allow also a comparison among activities having different dimensions.

\footnotetext{
${ }^{110}$ Mararo M. (1998), La struttura di gruppo nell'economia dell'impresa, Cedam, Bologna, pp. 203-256.
}

${ }^{111}$ Cf., Table 2, page 14. 


\section{Table 5}

Diagram for assessing the relationship among individual factor activities within the group

\begin{tabular}{|c|c|c|c|c|c|c|c|c|c|c|c|}
\hline \multirow[b]{2}{*}{ Activity } & \multicolumn{5}{|c|}{ Outsourced activity } & \multirow{2}{*}{$\begin{array}{l}\text { Internal } \\
\text { reference } \\
\text { person(s) }\end{array}$} & \multirow{2}{*}{$\begin{array}{c}\mathbf{N}^{\circ} \text { external } \\
\text { reference } \\
\text { persons }\end{array}$} & \multirow[b]{2}{*}{$\begin{array}{c}\text { Aim of } \\
\text { transactions }\end{array}$} & \multirow[b]{2}{*}{$\begin{array}{c}\text { Contact } \\
\text { frequency }\end{array}$} & \multirow[b]{2}{*}{$\begin{array}{l}\text { Exchange } \\
\text { frequency }\end{array}$} & \multirow[b]{2}{*}{$\begin{array}{l}N^{\circ} \text { employees in } \\
\text { factor's activity }\end{array}$} \\
\hline & $\begin{array}{c}\text { Not } \\
\text { outsourced }\end{array}$ & $\begin{array}{l}\text { Percentage } \\
\text { outsourced }\end{array}$ & $\begin{array}{c}\text { Towards } \\
\text { parent } \\
\text { company }\end{array}$ & $\begin{array}{c}\text { Towards } \\
\text { other } \\
\text { structures of } \\
\text { the group }\end{array}$ & $\begin{array}{c}\text { Towards external } \\
\text { outsourcer }\end{array}$ & & & & & & \\
\hline \multicolumn{12}{|c|}{$\begin{array}{l}\text { Relationship with } \\
\text { controlling partners and } \\
\text { contact with clients }\end{array}$} \\
\hline \multicolumn{12}{|c|}{ Preliminary investigation } \\
\hline \multicolumn{12}{|l|}{ Resolution } \\
\hline \multicolumn{12}{|l|}{ Payment } \\
\hline \multicolumn{12}{|l|}{$\begin{array}{l}\text { Relationship } \\
\text { management }\end{array}$} \\
\hline \multicolumn{12}{|c|}{ Renewals management } \\
\hline \multicolumn{12}{|c|}{$\begin{array}{c}\text { Late payments / } \\
\text { insolvency management }\end{array}$} \\
\hline \multicolumn{12}{|l|}{$\begin{array}{c}\text { Supervision and } \\
\text { coordination }\end{array}$} \\
\hline \multicolumn{12}{|l|}{$\begin{array}{c}\text { Management and } \\
\text { internal audit }\end{array}$} \\
\hline \multicolumn{12}{|l|}{ Information system } \\
\hline \multicolumn{12}{|l|}{ Human resources } \\
\hline \multicolumn{12}{|l|}{$\begin{array}{c}\text { Organizational } \\
\text { development }\end{array}$} \\
\hline \multicolumn{12}{|l|}{ Treasury } \\
\hline \multicolumn{12}{|c|}{$\begin{array}{c}\text { Fulfillment of law ad } \\
\text { corporate requirements }\end{array}$} \\
\hline General services & & & & & & & & & & & \\
\hline
\end{tabular}

Source: authors' elaboration 


\section{Conclusions}

Any analysis of the effectiveness of a group structure must take into account aspects related to the types of activity carried on by group members, any difference in the phases of the productive process that characterize individual businesses, problems linked to the adopted leadership approach, and difficulties in the interaction among the subjects involved in the corporate network. The problems linked to the differences within the enterprises involved increase in respect of groups made up by enterprises offering different products and/or services, such as finance conglomerates.

The study of the characteristics of the services rendered by entities belonging to a financing group does not point to problems linked to the risk of an inner cannibalization among financial products, and the study of the productive process of factoring companies permits to define a hierarchy of primary and support activities giving rise to higher/lower synergies with the other intermediaries of the group.

Having defined the areas of contact among the various intermediaries, one needs to probe into the effectiveness of the organizational structure that has been adopted. The recourse to a few social network analysis indicators allows ascertaining whether the level of integration/control existing in the individual areas coincides with the level of integration being pursued and, in case of need, it permits to identify areas of intervention to improve the organizational setup.

The analysis of the profiles that are relevant for determining the greater or lower success of the merger of a factoring company with a banking group does not exhaust the problems linked to the adopted organizational setup. Previously published studies have shown that, in most cases, the corporate governance of an enterprise is likely to affect results although, so far, there are no empirical analyses that may prove the soundness of such a principle in the factoring market. ${ }^{112[112]}$

The Italian situation, characterized by the contemporary presence of independent factoring companies and factoring companies belonging to banking groups, may prove a useful sample of analysis to probe into the relationship between corporate performance and level of the relationships among group members and/or type of control wielded by the parent company. Such an approach is likely to outgrow the standard methodologies used up to now that fail to discriminate within financial conglomerates the characteristics of their organizational setup and the level of integration among the intermediaries involved ${ }^{113[13]}$ and to offer the opportunity to assess whether or not there is a relationship between existing synergies and results attained by the group.

\footnotetext{
112 Hutchinkson M. and Gul F.A. (2004), "Investment opportunity set, corporate governance practice and firm performance", Journal of Corporate Governance, vol. 10, pp. 595-614.

113 See, for instance, De Nicolò G. et al. (2004), "Bank consolidation, internationalization and conglomeration: trends and implications for financial risk", Financial Markets, Institutions and Instruments, vol. 13, pp. 173-217.
} 


\section{Bibliography}

Ahuja G. (2000), "Collaboration networks, structural holes and innovation: a longitudinal study", Administrative Science Quarterly, vol. 45, pp. 425-455

Alba R.D. (1973), "A graph theoretic definition of a sociometric clique", Journal of Mathematical Sociology, vol. 3, pp. 113-126

Alexander C.N. (1963), "A method of processing sociometric data”, Sociometry, vol. 26, pp. 268269

Amel D. et al. (2002), Consolidation and efficiency in the financial sector: a review of the international evidence, Temi di discussione Banca d'Italia, no.464

Anderson M.C. et al. (2003), “Are selling, general and administrative costs 'sticky'?”, Journal of Accounting Research, vol. 41, pp. 47-63

Araten M. et al. (2004), "Measuring LGD on commercial loans: a 18-years internal study", RMA Journal, vol. 86, pp. 96-103

Bakker M.R. et al. (2004), Financing small and medium-size enterprise with factoring: global growth and its potential in eastern Europe, World Bank working paper no. 3342

Bakker M.R. and Gross A. (2004), Development of non-bank financial institutions and capital markets in the European Union accession countries, World Bank working paper no. 28

Banca d'Italia, Relazione annuale, various years

Baravelli M. (2003), Strategia e organizzazione della banca, Egea, Milano

Bavelas A. (1948), "A mathematical model for group structure", Human organization, vol. 7, pp. 16-30

Bavelas A. (1950), "Communication patterns in task-oriented groups", Journal of the Acoustical Society of America, vol. 22, pp. 271-282

Becht M. et al. (2002), Corporate governance and control, NBER working paper no. 9371, Cambridge

Benvenuti M. and Gallo M. (2004), Perché le imprese ricorrono al factoring? Il caso dell'Italia, Temi di discussione Banca d'Italia no.518

Beretta S. (1990), Il controllo dei gruppi aziendali, Egea, Milano

Berger A. (2000), "The integration of financial services industry: where are the efficiencies?", North American Actuarial Journal, vol. 4, pp. 25-52

Berger A.N. and Hannan T.H. (1998), "The efficiency cost of market power in the banking industry: a test of the 'quiet life' and related hypotheses", Review of Economics and Statistics, vol. 80 , pp. 454-465

Berger A.N. and Udell G.F. (1995), "Relationship lending and lines of credit in small firm finance", Journal of Business, vol. 68, pp. 351-381

Bertinetti G. (2004), "La finanza dei gruppi aziendali" in Dallocchio M. and Salvi A., Finanza d'azienda, Egea, Milano, pp. 603-820

Bethel J.E. and Porter Liebeskind J. (1998), "Diversification and the legal organization of the firm", Organization Science, vol. 9, pp. 49-67

Blois K.J. (1972), "Vertical quasi integration", Journal of Industrial Economics, vol. 20, pp. 253272

Bock R.D. and Husain S.Z. (1952), "An adaptation of Holzinger's B-coefficients for the analysis of sociometric data", Sociometry, vol. 15, pp. 206-219

Boczar G.E. (1976), Competition between banks and finance companies: a cross section study of personal loan debtors, CRC working paper

Borgatti S.P. (2005), "Centrality and network flows", Social Networks, vol. 27, pp. 55-71 
Boudreau J.W. and Ramstad P.M. (2005), "Talentship, talent segmentation and sustainability. A new HR decision science paradigm for a new strategy definition”, Human Resource Management, vol. 44, pp. 129-136

Boyd J.H. and Graham S.L. (1998), "The profitability and risk effects of allowing bank holding companies to merge with other financial firms: A simulation study", Federal Reserve Bank of Minneapolis Quarterly Review, vol. 12, pp. 3-20

Carey M. et al. (1998), "Does corporate lending by banks and finance companies differ? Evidence on specialization in private debt contracting", Journal of Finance, vol. 53, pp. 845-878

Carretta A,. (1986), "Le banche e la gestione delle attività non bancarie", in Carretta A. and Anderloni L., Banche e parabancario, Giuffrè Editore, Milano

Carretta A. (1986), "Le banche e la gestione delle attività non bancarie: alcuni profili organizzativi”, Banca, Impresa e Società, vol. 1, pp. 81-95

Carretta A. (1991), "Analisi del modello istituzionale del gruppo plurifunzionale: condizioni di dimensione per il funzionamento", in Vanciago G. (1991) Manuale per il 1993 e oltre - scelte strategiche e organizzative, Edibank, Milano

Carretta A. (1991), "Un confronto tra banche e istituzioni finanziarie non bancarie", in Carretta A. (edited by), Le istituzioni finanziarie non bancarie, Egea, Milano

Carretta A. (1995), Il factoring, Ricerche Newfin - Università Commerciale Bocconi, Milano, pp. 43-49

Carretta A. (1998), "Effetti della formazione di aggregati bancari sul comportamento e sulle performance delle istituzioni finanziarie", in Aidea (1998), Atti del convegno "strategie e politiche aziendali ", CLUEB, Bologna

Casu B. and Girardone C. (2004), "Financial conglomeration: efficiency, productivity and strategic drive", Applied Financial Economics, vol. 14, pp. 687-696

Chung A.S. (1996), "Performance effects of cooperative strategies among investment banking firms: a loglinear analysis of organizational exchange networks", Social Networks, vol. 18, pp. 121-148

Clarizia R. (2002), I contratti per il finanziamento dell'impresa. Mutuo di scopo, leasing e factoring, Giappichelli editore, Torino

Coase R.H. (1937), "The nature of the firm", Economica, vol. 4, pp. 386-405

Corvi E. (1989), Il gruppo nell'economia dell'azienda industriale, Egea, Milano

Cross R. et al. (2002), Making invisible work visible: using social network analysis to support strategic collaboration, University of Virginia working paper

De Angeli S. (1995), "Il processo di trasformazione dell'industria bancaria", in Scott W., Manuale di marketing bancario, Utet, Torino

De Canio S et al. (2000), "The importance of organizational structure for the adoption of innovations", Management Science, vol. 46, pp. 1285-1299

De Nicolò G. et al. (2004), "Bank consolidation, internationalization and conglomeration: trends and implications for financial risk", Financial Markets, Institutions and Instruments, vol. 13, pp. $173-217$

Demattè et al. (1993), Economia degli intermediari finanziari, Egea, Milano, pp. 433-532

Eccles R.J. (1981), "The quasi firm in the construction industry", Journal of Economic Behavior and Organization, vol. 2, pp. 335-357

Dougherty D. (1992), "Interpretative barriers for successful product innovation in large firms", Organization Science, vol. 3, pp. 179-202

Economides N. (1996), "The economics of network", International Journal of Industrial Organization, vol. 14, pp. 673-699

Eslyn L.J.B. (2005), "Information monopoly and commitment in intermediary-firm relationships", Journal of Financial Services Research, vol. 27, pp. 5-26 
Forestieri G. and Mottura P. (2004), Il sistema finanziario. Istituzioni, mercati e modelli di intermediazione, Egea, Milano

Fossati G. and Porro A. (1985), Il factoring, Giuffrè Editore, Milano

Freeman L.C. (1977), "A set of measures of centrality based on betweenness", Sociometry, vol. 40 , pp. $35-41$

Freeman L.C. (1979), “Centrality in social networks: conceptual clarification”, Social Networks, vol. 1, pp. 215-239

Galaskiewicz J. (1985), "Interorganizational relations", Annual Review of Sociology, vol. 11, pp. 281-304

Gladstein Ancona D. and Caldwell D.F. (1992), "Demography and design: predictors of new product team performance", Organization Science, vol. 3, pp. 321-341

Grandori A. (1997), "Governance structure, coordination mechanism and cognitive models", Journal of Management and Governance, vol. 1, pp. 29-47

Grandori A. and Soda G. (1995), "Inter-firm networks: antecedents, mechanisms and forms", Organization Studies, vol. 16, pp.183-214

Grandori A. and Soda G. (2004), "Governing with multiple principals: an empirically based analysis of capital providers' preferences and superior governance structures", in Grandori A. (2004), Corporate governance and firm organization, Oxford University Press, New York

Granovetter M.S. (1973), "The strength of weak ties", American Journal of Sociology, vol. 78, pp. $1360-1380$

Gyongyi L. (2000), Financial conglomerates: innovation, scope economies and incentives, Birbek college working paper, London

Hillyer W.H. (1939), "Four centuries of factoring", Quarterly Journal of Economics, vol. 53, pp. 305-311

Holmer M.R. and Zenios S.A. (1995), "The productivity of financial intermediation and the technology of financial product management”, Operational Research, vol. 43, pp. 970-982

Hutchinkson M. and Gul F.A. (2004), "Investment opportunity set, corporate governance practice and firm performance", Journal of Corporate Governance, vol. 10, pp. 595-614

Inselbag I. (1973), "Financing decisions and the theory of the firm", Journal of Financial and Quantitative Analysis, vol. 8, pp. 763-776

Jehn K.A. (1997), "A qualitative analysis of conflict types and dimension in organizational groups", Administrative Science Quarterly, vol. 42, pp. 530-557

Khatry N. et Alvin H. (2000), "Role of intuition in strategic decision making", Human Relations, vol. 53, pp. 57-86

Lang G. and Welzel P. (1998), "Technology and cost efficiency in universal banking. A 'thick' frontier. Analysis of German banking industry", Journal of Productivity Analysis, vol. 10, pp. 63-84

Lei D. et al. (1999), "Designing organization for competitive advantage: the power of unlearning and learning", Organizational Dynamics, vol. 27, pp. 24-38

Lown C.S. et al. (2000), "The changing landscape of the financial service industry: what lies ahead", Federal Reserve Bank of New York Policy Review, vol. 6, pp. 39-55

Mariti P. and Smiley R.H. (1983), "Cooperative agreements and the organization of industry", Journal of Industrial Economics, vol. 31, pp. 437-451

Masini M. (1999), Gruppo bancario ed efficacia nella gestione del rapporto bancacliente, Quaderni del dipartimento di Economia Aziendale, Università di Bergamo

Mararo M. (1998), La struttura di gruppo nell'economia dell'impresa, Cedam, Bologna

Mendes P.M. et al. (1988), "Dynamic aspects of decision making, paper submitted at the "Engineering Management Conference", Dayton, USA 
Milliken F.J. and Martins L.L. (1996), "Searching for common threads: understanding the multiple effects of diversity in organizational groups", Academy of Management Review, vol. 21, pp. 402-433

Monferrà S. (1998), "Regolamentazione e intermediari finanziari non bancari: alcune evidenze sui differenti comportamenti aziendali", in Carretta A. (edited by), Banche e intermediari non bancari: concorrenza e regolamentazione, Bancaria Editrice, Roma

Monferrà S. (2003), "Il factoring: servizi di gestione , assicurazione e finanziamento", in Fabrizi P.L. et al (edited by), Strumenti e servizi finanziari, Egea, Milano

Murray A.I. (1989), "Top management group heterogeneity and firm performance", Strategic Management Journal, vol. 10, pp. 125-141

Newman M.E.J. (2005), “A measure of betweeness centrality based on random walks", Social Networks, vol. 27, pp. 39-54

Oliver C. (1991), "Strategic responses to institutional processes", Academy of Management Review, vol. 16, pp. 145-169

Osborn R. (1950), "The relative efficiency of large, medium-sized and small business", Accounting Review, vol. 25, pp. 262-273

Paape L. et al. (2003), "The relationship between internal audit function and corporate governance in the EU - A survey", International Journal of Auditing, vol. 7, pp. 247-262

Peay E.R. (1980), "Connectedness in a general model for valued networks", Social Networks, vol. 2, pp. 385-410

Peel M.J. et al. (1999), Late payment and credit management in the small firm sector: some empirical evidence, CMRC working paper, Leeds

Peppard J. (2000), "Customer Relationship Management (CRM) in financial services", European Management Journal, vol. 18, pp. 312-327

Phillips A. (1960), “A theory of interfirm organization”, Quarterly Journal of Economics, vol. 74, pp. 602-613

Pitts F.R. (1979), "The medieval river trade network of Russia revisited”, Social Networks, vol. 1, pp. 285-292

Porter M. (1981), "The contributions of industrial organization to strategic management", Academy of Management Review, vol. 6, pp. 609-620

Porter M. (1987), Il vantaggio competitivo, Edizioni Comunità, Milano

Previati D. (1995), "Gli assetti organizzativi delle banche", in Scott W., "Manuale di marketing bancario", Utet, Torino

Reichert A.K. and Wall L.D. (2000), "The potential for portfolio diversification in financial services", Federal Reserve Bank of Atlanta Economic Review, vol. 85, pp. 35-51

Richardson D. (1993), “A factor in your future”, Engineering Management Journal, vol. 3, pp. 278-280

Richardson G.B. (1972), “The organization of industry”, The Economic Journal, vol. 82, pp. 883896

Rodgers D.L. (1974), "Sociometric analysis of interorganizational relations: application of theory and measurement", Rural Sociology, vol. 39, pp.487-503

Ruozi R. and Rossignoli B. (1985), Manuale del factoring, Giuffrè Editore, Milano

Schleifer A. and Vishny R. (1995), A survey of corporate governance, NBER working paper no. 5554, Cambridge

Schwizer P. (1984), "I modelli istituzionali e l'assetto organizzativo", in Ruozi R. and Carretta A. (edited by), "Manuale del leasing", Giuffrè, Milano

Schwizer P. (1996), La diversificazione bancaria, Egea, Milano 
Schwizer P. (1998), "Le politiche del personale: elementi di differenziazione e di integrazione", in Airoldi et al., La gestione del personale nei gruppi bancari. Strategia e pianificazione organizzativa, Bancaria Editrice, Milano

Schwizer P. (1998), "I modelli di corporate governance negli intermediari finanziari ad azionariato diffuso", in Airoldi G. and Forestieri G., Corporate governance. Analisi e prospettive del caso italiano, Etas Libri, Milano, pp. 344-364

Sopranzetti B.J. (1998), “The economics of factoring accounts receivables”, Journal of Economics and Business, vol. 50, pp. 339-359

Soufani K. (2002), "The decision to finance account receivables: the factoring option", Managerial and Decision Economics, vol. 23, pp. 21-32

Summers B. and Wilson N. (2000), "Trade credit management and the decision to use factoring: an empirical study", Journal of Business, Finance \& Accounting, vol. 27, pp. 37-68

Teece D.J. (1980), "Economies of scope and the scope of enterprise", Journal of Economic Behavior and organization, vol. 1, pp. 223-247

Teece J. (1989), "Inter-organizational requirements of the innovation process", Managerial and Decision Economics, vol. 10, pp. 35-42

Thompson J.D. (1967), Corporate in Action, Mc Graw Hill, New York

Thorburn K.S. (2000), "Bankruptcy auctions: costs, debt recovery and firm survival", Journal of Financial Economics, vol. 58, pp. 337-368

Turati C. (1990), Economia ed organizzazione delle joint ventures, EGEA, Milano

Udell G. (2004), Asset based finance, Commercial Finance Association, pp. 81-88

Van de Ven A.H. (1976), "A framework of organization assessment", Academy of Management Review, vol. 1, pp. 64-78

Van Lelyveld I. and Schilder A. (2003), Risk in financial conglomerates: management and supervision, Brooking and Warthon papers on Financial Services, London

Vander Vennet R. (2002), "Cost and profit efficiency of financial conglomerates and universal banks in Europe", Journal of Money, Credit and Banking, vol. 34, pp. 254-282

Walter I. (1999), Financial services strategies in the Euro zone, Stern Working paper, New York

Wasserman S. and Faust K. (1994), Social network analysis, Cambridge University Press, Cambridge

Whalen G. (1997), Bank organization form and the risks of expanded activities, OCC Economics Working Paper

Williams M. (2003), Interpersonal action across organizational boundaries: threat and trust in the contest of social network diversity, MIT Sloan School of Management working paper, Cambridge

Williamson O.E. (1975). Markets and Hierarchies: Analysis and Antitrust Implications. Free Press, New York

Williamson O.E. (1981), "The economics of organization: the transaction cost approach", American Journal of Sociology, vol. 87, pp. 548-577

Williamson O.E. (1985), The economic institutions of capitalism, Free Press, Oxford

Yang S. and Knoke D. (2001), "Optimal connections, strength and distance in valued graphs", Social Networks, vol. 23, pp. 285-295

Zach M.H. (2000), "Researching organizational system using social network analysis", Proceedings of 33rd International Conference on System Sciences, Maui, Hawaii

Zemljic B. and Hlebec V. (2005), Reliability of measures of centrality and prominence", Social Networks, vol. 27, pp. 73-88 